Matematikai Közlemények

IV. kötet, 2016

doi:10.20312/dim.2016.08

\title{
Lehűlési folyamat vizsgálata középiskolai módszerekkel
}

\author{
Barta Edit \\ NymE EMK Matematikai Intézet \\ barta.edit@nyme.hu
}

\begin{abstract}
ÖSSZEFOGLALÓ. Egy konkrét példán keresztül szeretném bemutatni, hogy a lehülési és azzal analóg folyamatok hogyan tárgyalhatók középiskolai matematikai módszerekkel, és az eredmény hogyan egyeztethető össze a differenciálegyenlettel való megoldás eredményével.

ABSTRACT. I wish to present a possible treatment of cooling-, and analogous processes using only basic mathematical techniques for solving a proper example. I compare the result to the solution gained by a differential equation.
\end{abstract}

\section{Bevezetés}

A középiskolai fizika oktatása során jó néhány példa található arra, hogy a tárgyalt jelenség analitikai megközelítését olyan problémák teszik lehetetlenné, hogy a diák nincs birtokában azoknak a matematikai ismereteknek, amelyek az adott probléma megoldását egzaktul szolgáltatnák. Egyik ilyen jelenségcsoport a lehülési folyamatok és az azzal analóg jelenségek, mint például a radioaktív bomlás, vagy az egyenáramú áramköröknél az áram megszakításakor lejátszódó tranziens jelenségek. De ezekhez hasonlóan tárgyalhatók a telítődési jellegű folyamatok, mint például az adott külső hőmérsékletre történő felmelegedés vagy az áram bekapcsolásakor lejátszódó tranziens folyamatok. A közös bennük az, hogy hasonló alakú differenciálegyenlet írható fel mindegyik folyamatra, amelynek a megoldása egyszerü, ámde a differenciál- és integrálszámítást nem tanuló középiskolásnak nem tálalható. Néhány esetben viszont - amikor a feladat számadatai „szépek” - az egzakt megoldást szolgáltató függvény egészen jól közelíthető csak középiskolás matematikai eszközöket felhasználva. Ennek bemutatására alkalmas az alábbi feladat, amely évekkel ezelőtt a Nyugatmagyarországi Egyetemen oktatott Matematika II. tantárgy differenciálegyenletek témakörének bevezető példája volt [1]. Ezt a feladatot éppen „szép” számadatai és viszonylag egyszerü, ámde ötletet kívánó megoldása miatt kitüztük a 2016-os Vermes Miklós Nemzetközi Fizikaverseny Hőtan kategóriájában is [2].

\section{A konkrét feladat}

„A kemencéből kiszedett kenyér hőmérséklete $120{ }^{\circ} \mathrm{C}, 30$ perccel később $60{ }^{\circ} \mathrm{C}$. Mikor lesz a kenyér hőmérséklete $40{ }^{\circ} \mathrm{C}$, ha az időben állandó külső hömérséklet $30{ }^{\circ} \mathrm{C}$ ? A megoldáshoz alkalmazza a Newton-féle lehülési törvényt, mely szerint egy test hőmérsékletváltozásának a sebessége arányos a test és a környezete közötti hőmérsékletkülönbséggel." 


\section{Megoldások}

Három megoldást fogok ismertetni, amelyekből az első az egzakt hőmérséklet-idő függvényt szolgáltató differenciálegyenletes megoldás, a másik kettő pedig a középiskolásoknak is bemutatható eljárás. Mindhárom megoldás során használjuk a következő jelöléseket:

$T, T(t)$ : a kenyér pillanatnyi hőmérséklete,

$T_{0}:$ a kenyér kezdeti hömérséklete $\left(T_{0}=120^{\circ} \mathrm{C}\right)$,

$T_{k}:$ a külső hőmérséklet $\left(T_{k}=30^{\circ} \mathrm{C}\right)$,

$t_{m}:$ a későbbi mérésig eltelt idő $\left(t_{m}=30\right.$ perc $)$,

$T_{m}:$ a $t_{m}$ időpontban mért hömérséklet $\left(T_{m}=60^{\circ} \mathrm{C}\right)$.

\section{Megoldás}

A Newton-féle lehülési törvény differenciális alakja:

$$
\frac{d T}{d t}=\propto\left(T-T_{k}\right)
$$

Ez egy szétválasztható változójú közönséges differenciálegyenlet, melynek a kezdeti feltételeket is figyelembe vevő megoldása:

$$
T(t)=\left(T_{0}-T_{k}\right) e^{\propto t}+T_{k},
$$

ahol $\alpha$ 1/idő dimenziójú mennyiség, a későbbi időpontban mért eredményekből meghatározandó állandó. Behelyettesítve a mért adatokat a megoldásba:

$$
\begin{gathered}
T_{m}=\left(T_{0}-T_{k}\right) e^{\propto t_{m}}+T_{k}, \\
\propto=\ln \left(\frac{T_{m}-T_{k}}{T_{0}-T_{k}}\right)^{\frac{1}{t_{m}}}
\end{gathered}
$$

kifejezést kapjuk $\alpha$-ra. Ezt visszahelyettesítve a megoldásba és az átalakításokat elvégezve a következő exponenciális függvényt kapjuk a kenyér pillanatnyi hőmérsékletére:

$$
T(t)=\left(T_{0}-T_{k}\right)\left(\frac{T_{m}-T_{k}}{T_{0}-T_{k}}\right)^{\frac{t}{t_{m}}}+T_{k}
$$

Általában $\alpha$-t vagy kiszámolják szám szerint, és beírják $e$ kitevőjébe, vagy kísérletekből meghatározandó paraméterként tüntetik fel, de a hőmérséklet-idő függvényt mindenképpen $e$ alapú exponenciális függvényként írják fel. Most azért célszerü mégis paraméteresen visszahelyettesítenünk az $e$ alapú függvénybe és egyszerüsítenünk, hogy az így kapott megoldást össze tudjuk hasonlítani a középiskolás megoldás eredményével.

Megjegyezzük, hogy a radioaktív bomlástörvényt is két alakban szokták megadni, az egyik $\left(N=N_{0} e^{-\lambda t}\right) e$, a másik $\left(N=N_{0} 2^{-\frac{t}{T}}\right) 2$ alapú exponenciális függvény. A $\lambda$ bomlási állandó és a $T$ felezési idő között analóg kapcsolat áll fenn, mint esetünkben az $\alpha$ és a $t_{m}$ között.

\section{Megoldás}

A lehülési törvény értelmében

$$
\frac{\Delta T}{\Delta t} \sim T-T_{k}
$$

Célszerüen $\Delta t$-t válasszuk 1 percnek, ez „elég kicsi”. Így a lehülési törvény alakja: 


$$
\Delta T=c\left(T-T_{k}\right),
$$

ahol $\Delta T$ az 1 percre jutó hőmérsékletcsökkenés, $c$ a mért eredményekből meghatározandó arányossági tényező.

Jelölje $\Delta T_{0}$ a $[0 ; 1], \Delta T_{1}$ az [1;2], $\Delta T_{2}$ a [2;3], $\ldots, \Delta T_{n-1}$ az $[n-1 ; n], \ldots$ perc időintervallumban bekövetkező hőmérsékletcsökkenést (pozitív előjellel!), $T_{0}, T_{1}, T_{2}, \ldots T_{n} \ldots$ pedig a kenyér hömérsékletét a $t=0,1,2, \ldots n, \ldots$ perc időpillanatokban. A megoldást $T_{n}$ fogja szolgáltatni.

A hőmérsékletcsökkenésekre felírható:

$$
\begin{gathered}
\Delta T_{0}=c\left(T_{0}-T_{k}\right)=c T_{0}-c T_{k}, \\
\Delta T_{1}=c\left(T_{1}-T_{k}\right)=c T_{1}-c T_{k}, \\
\Delta T_{2}=c\left(T_{2}-T_{k}\right)=c T_{2}-c T_{k}, \\
\vdots \\
\Delta T_{n-1}=c\left(T_{n-1}-T_{k}\right)=c T_{n-1}-c T_{k},
\end{gathered}
$$

A hőmérsékletekre felírható:

$$
\begin{gathered}
T_{1}=T_{0}-\Delta T_{0}=T_{0}-c T_{0}+c T_{k}=T_{0}(1-c)+c T_{k}, \\
T_{2}=T_{1}(1-c)+c T_{k}, \\
T_{3}=T_{2}(1-c)+c T_{k}, \\
\vdots \\
T_{n}=T_{n-1}(1-c)+c T_{k},
\end{gathered}
$$

Ily módon az egész percekben mérhető hőmérsékletekre egy rekurzív módon megadott sorozatot írtunk fel. Ennek általános tagja a behelyettesítéseket és megfelelő kiemeléseket végrehajtva a következő alakban írható fel:

$$
T_{n}=T_{0}(1-c)^{n}+c T_{k}\left[(1-c)^{n-1}+(1-c)^{n-2}+\cdots+(1-c)+1\right] .
$$

A szögletes zárójelben levő összeg egy olyan mértani sorozat első $n$ tagjának az összege, amelynek első tagja 1, kvóciense (1-c). Zárt formában felírva az összeget:

$$
S_{n}=a_{1} \frac{q^{n}-1}{q-1}=1 \frac{(1-c)^{n}-1}{1-c-1}=\frac{1-(1-c)^{n}}{c} .
$$

Ezt behelyettesítve $T_{n}$-be és az átalakításokat elvégezve kapjuk:

$$
T_{n}=\left(T_{0}-T_{k}\right)(1-c)^{n}+T_{k} .
$$

A $c$ paramétert illetve az 1-c mennyiséget a 30 . perc végén mért hőmérsékletből határozhatjuk meg.

$$
\begin{gathered}
T_{m}=\left(T_{0}-T_{k}\right)(1-c)^{m}+T_{k} \\
1-c=\left(\frac{T_{m}-T_{k}}{T_{0}-T_{k}}\right)^{\frac{1}{m}} .
\end{gathered}
$$

Visszahelyettesítve a következő megoldást kapjuk: 


$$
T_{n}=\left(T_{0}-T_{k}\right)\left(\frac{T_{m}-T_{k}}{T_{0}-T_{k}}\right)^{\frac{n}{m}}+T_{k}
$$

Megoldásunk tehát egy számsorozat, méghozzá egy mértani sorozat, amelynek tagjai az egész percekben mérhető hőmérsékletet adják meg.

Hasonlítsuk össze (1)-gyel, azaz a differenciálegyenlettel kapott megoldással! Látható, hogy a két megoldás teljesen hasonló, mindössze annyi a különbség, hogy míg (1) folytonos függvény, amelynek értelmezési tartománya a nem negatív valós számok, addig (2) egy olyan diszkrét függvény, amelynek értelmezési tartománya a természetes számok halmaza. Az egész percnyi időpillanatokban a két függvény azonos értékeket vesz fel. De ennél több is teljesül: ha az időt továbbra is percekben számoljuk, akkor tetszőleges, nem feltétlenül egész percet is behelyettesíthetünk (2)-be, a kapott hőmérsékleti érték pontos lesz! Egyetlen átírással ( $n$ helyett $t$ ) folytonossá tehetjük a sorozatunkat, és megkapjuk az egzakt megoldást.

A konkrét feladat megoldása adatainkkal:

$$
T_{n}=90\left(\frac{1}{3}\right)^{\frac{n}{30}}+30
$$

illetve

$$
T(t)=90\left(\frac{1}{3}\right)^{\frac{t}{30}}+30
$$

A feladat kérdése, hogy mely $n$-re lesz $T_{n}=40^{\circ} \mathrm{C}$.

$$
40=90\left(\frac{1}{3}\right)^{\frac{n}{30}}+30
$$

Az exponenciális egyenletet megoldva $n=60$ adódik, tehát 60 perc múlva lesz a kenyér hömérséklete $40{ }^{\circ} \mathrm{C}$.

\section{Megoldás}

Van az előzőnél egyszerübb megoldás is, amely azon az ötleten alapul, hogy a hőmérsékleti skála nullpontját eltoljuk $+30{ }^{\circ} \mathrm{C}$-ba. Ezt megtehetjük, hiszen mind a hőmérsékletváltozás, mind pedig a hőmérsékletkülönbség független attól, hogy a hőmérsékleti skálán hol helyezkedik el a nullpont. A kiinduló adatok és a feladat kérdése a következőképpen módosul: $T_{0}=90{ }^{\circ} \mathrm{C}, T_{30}=30{ }^{\circ} \mathrm{C}, T_{k}=0{ }^{\circ} \mathrm{C}$. Mikor lesz a kenyér hőmérséklete $10^{\circ} \mathrm{C}$ ?

A lehülési törvényalakja:

$$
\frac{\Delta T}{\Delta t} \sim T
$$

$\Delta t$-t most is 1 percnek választjuk, így

$$
\Delta T=c T .
$$

Az (n-1)-edik hőmérsékletváltozás:

$$
\Delta T_{n-1}=c T_{n-1},
$$

a hőmérsékletek: 


$$
\begin{gathered}
T_{1}=T_{0}-\Delta T_{0}=T_{0}-c T_{0}=T_{0}(1-c) \\
T_{2}=T_{1}-\Delta T_{1}=T_{1}-c T_{1}=T_{1}(1-c)=T_{0}(1-c)^{2} \\
\vdots \\
T_{n}=T_{0}(1-c)^{n}
\end{gathered}
$$

A mért értéket behelyettesítve:

a keresett függvény:

$$
1-c=\left(\frac{T_{m}}{T_{0}}\right)^{\frac{1}{m}}
$$

$$
T_{n}=T_{0}\left(\frac{T_{m}}{T_{0}}\right)^{\frac{n}{m}} .
$$

A módosított adatok behelyettesítését és a végeredmény számszerü kiszámolását az olvasóra bízom.

Látható, hogy ez utóbbi megoldás sokkal egyszerübb az előzőnél, hátránya, hogy nem minden esetben alkalmazható.

\section{4. Összefoglaló}

Írásomban két lehetséges módszert ismertettem az exponenciális lecsengésủ folyamatok középiskolai matematikai eszközökkel való tárgyalására. A konkrét feladatot a verseny résztvevői közül senki nem az általam megadott megoldások valamelyikével dolgozta ki. Éppen a feladat „szép” számadatai tették lehetővé a feladat végeredményének megsejtését: „ha 30 perc alatt a kezdeti hőmérséklet a külsőhöz képest kétharmadára esik vissza, akkor innen további kétharmadára is feltételezhetően ugyanannyi idő alatt esik vissza." Ezen megsejtéshez alkotott a diákok egy része képletet, levezetést, és kapott helyes eredményt. Egy versenyző próbálkozott differenciálegyenlettel (ő birtokában volt ennek az ismeretnek), egy pedig megsejtette, hogy az ilyen jellegü folyamat „,valami exponenciális függvénnyel írható le", és ezen gondolat alapján oldotta meg a feladatot helyesen. Tanulság: a túlságosan szép számadatok néha megfosztják a tanárt attól a lehetőségtől, hogy megmutassa az általánosabb, szélesebb körben is alkalmazható megoldást.

\section{Irodalomjegyzék}

[1] Horváth, J., Matematika II., Egyetemi jegyzet, Soproni Egyetem, EMK, Matematikai Intézet, Sopron, (1998), p. 42.

[2] Hőtan kategória feladatlapja, Vermes Miklós Fizikaverseny, 2016. 